\title{
APPENDIX
}

\section{Methods for Calibration and Standardization of \\ Photographic Plates used at Utrecht}

By M. MinnaerT, Utrecht

\section{Calibration}

The calibration of plates at our laboratory is ordinarily obtained by one of the following three methods:

The step reducer. A thin glass plate, platinized in steps of varying thickness, is put on the slit of the spectrograph, and the spectrum is obtained at once in strips corresponding to known intensities. The transmission of the steps has been determined once for all, e.g. with a thermopile.

The step slit. The spectrograph slit is replaced by a special slit, of which the width varies in steps; with a continuous source of light the intensities are proportional to the slit widths.

The variation of current. A series of consecutive exposures is made on a standardized lamp, burning at different electric currents.

Each of these methods has its peculiar advantages and disadvantages, depending on the object of the investigation.

\section{The Calibration of a Solar Spectrum}

With a step reducer, we are ready at once without any additional exposure. There may be some danger, that a slit, so narrow that it gives a fine definition, has not a perfectly constant width over its whole length; the remedy: take a first spectrogram with a narrow slit, a second one with a wide slit and a uniform auxiliary reducer which reduces the intensity to about that of the narrow slit; this second exposure furnishes the intensity scale. The step reducer method has the advantage, that it automatically corrects for the influence of false light in the spectrograph, provided this false light extends equally over all the spectral strips; the density curve is slightly distorted, but just over the amount necessary to correct the spectrum under investigation, which is also contaminated by false light. No step reducers are really neutral, the transmission therefore has to be measured in the different wavelengths; this calibration is not easy in the ultraviolet, because the energy of our ordinary sources of light is small there.

The step slit has the advantage, that its transmission factors are independent of the wave-length. It has the disadvantage, that there is always a danger of diffraction if the slits are not wide enough, so that part of the light would not reach the grating; moreover, the illumination through each of the steps will not be distributed exactly according to the same law over the grating, and this, combined with the unequal brightness of the different parts of the grating, will introduce a source of error. If the slits are too small, there may be even produced some polarization. The method does not seem perfect when a high accuracy is required, especially with a grating spectrograph.

The method of current variation gives very beautiful density curves, but a long series of additional exposures is necessary. In this case there is no automatic correction for the false light. But the density curves obtained are perfect from a photographic point of view, because you vary the amount of false light in the same proportion as the light proper. The method of current variation is of great value for 
the exact determination of the transmission of a step reducer: it is not always safe to rely upon the transmission as measured outside the optical train (the reducer might scatter, or some steps might be slightly prismatic). Now we can put a calibrated lamp before our spectrograph and take a series of exposures with varying current; after that we take a series with constant current but with interposition of the consecutive steps of our reducer; by comparison and interpolation the transmission of the steps is determined. This method also applies to the ultraviolet. In this way the advantage of a standardization in the exact optical conditions of the spectrograph is combined with the advantages of the step reducer.

\section{The Calibration of a Star Spectrum}

Consider now the possibility of applying these methods to the calibration of a star spectrum. Here, the density marks must be obtained from an auxiliary source of light, a standardized lamp. When the star spectrum is exposed, the false light is negligible, the length of the slit illuminated being so small; so in making the density marks, the false light should be avoided also. The best way would be to standardize with current variation, illuminating the slit only over a very small length. But here another far more important consideration comes in: the plate should be calibrated with an exposure time approximating to that of the star spectrum itself. This implies that practically the calibration by a step reducer or a step slit is the only one possible. It is easy to avoid false light, if every step is reduced to a very small width; then at the same time the advantage is obtained, that all sorts of Eberhard effects are the same for the standards as for the star spectrum. It would be best in all respects if the standard spectrum could be photographed at the same time as the star spectrum and during the same length of time.

\section{Step Reducers}

We make our reducers by cathodic sputtering of platinum, evaporation being difficult because the melting point of platinum is so high. We found that an atmosphere of nitrogen will do just as well as one of inert gases, if only it is quite free of oxygen; the purest industrial nitrogen in bombs is pure enough for the purpose, and this greatly facilitates the technique. It is very curious that the scattering of light by $P t$-reducers is so small, because most metallic layers, when thin, are composed of separate particles, in the manner of colloids. However, a preliminary examination under the ultramicroscope failed to show granular structure in most of the sputtered $P t$ layers; this, if confirmed, would explain why the scattering is absent.

It is hardly necessary to say that step reducers should be made on optically plane glass, especially for solar work, where the grating is seen under such a small angle. The reducer should never be covered by a cover glass: ( $I$ ) this would deteriorate the optical quality; (2) it gives rise to very troublesome interferences, which only disappear by the interposition of canada-balsam or cedar oil; (3) but if you interpose such substances, the absorption in the ultraviolet may increase very steeply and may vary from point to point in a dangerous way (10).

In my experience, $P t$ step reducers are astonishingly constant; in the course of six years our reducers did not show a change greater than the errors of measurement.

\section{Standardized Lamps}

Standardized lamps are used in two types: spiral lamps and ribbon lamps. Spiral lamps are used for ordinary work, and when an image of the lamp may not be 
formed on the slit. They burn at a current of only 2-4 amps. Ribbon lamps are used for exact work and when an image of the source is formed on the slit; they burn at I2-I7 amps. Note some peculiarities of our newest type (Fig. I) : extremities of the ribbon folded backwards and thus invisible; reflected images avoided by a light trap; quartz window, at a great distance from the lamp, so that there is hardly any deposit formed on it; a duplicate window is added, so that the absorption and reflection of it may be determined. Even with these precautions, only a carefully selected lamp out of a whole batch will be really satisfactory; otherwise, phenomena of recrystallisation in the ribbon may give anomalous variations in the light, while the current is kept entirely constant. It should be noted that the temperature is not quite the same over the whole length of the ribbon.

For exact work, the intensity distribution of a lamp should not be characterized by a colour temperature $\left(T_{0}\right)$. Glowing tungsten has more or less a colour temperature between $\lambda 4000$ and $\lambda 7000$, but as soon as we go beyond these limits, the value of $T_{0}$ changes. If it exists in a certain region, it is by a combination of fortuitous circumstances: the emission coefficient depends on the wave-length; the window

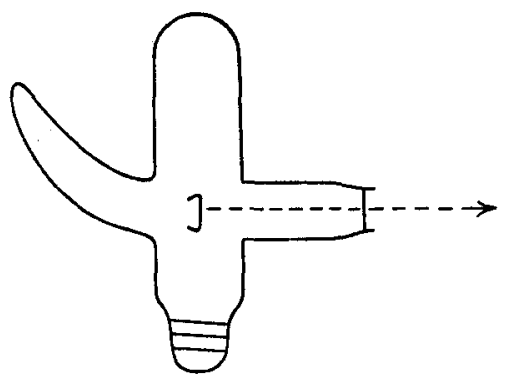

Fig. 1 .

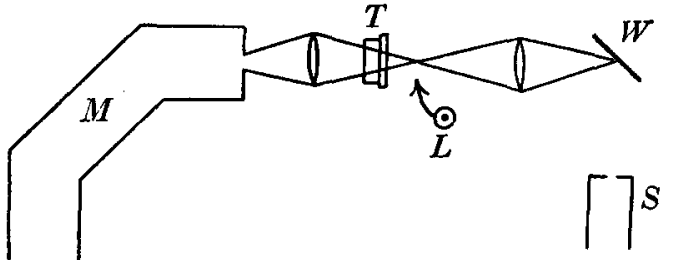

Fig. 2 .

absorbs and reflects; if the lamp is a spiral lamp, the first and last turns have too low a temperature; in the inside of the spiral you see a reflection of the other turns, so the inside is brighter than the outside and has another energy distribution. It is therefore better to avoid the concept of colour temperature in exact work.

For many problems a determination of the relative energy distribution will be sufficient. In other cases, the requirements of theory make urgent the need of absolute photometric determinations, especially where we are able to measure a surface brightness, as for the sun and for nebulae; an absolute standardization of our lamps must then be carried out.

Primary standardization. A method was devised by Prof. Ornstein and worked out by himself and his collaborators, in order to measure directly the energy distribution in a lamp after elimination of the absorption of the monochromator (Fig. 2). (I) The radiation of an auxiliary lamp $A$ is measured with a monochromator $M$ and thermopile $T$ in different wave-lengths. (2) Then this same radiation is projected on a white diffusing screen $W$, from it in a spectral pyrometer $S$ (visual or with a photocell), and the deflection at each wave-length is determined. (3) Finally the auxiliary lamp with its monochromator are replaced by the lamp $L$ to be investigated, and this also is measured with the same spectral pyrometer. The spectral pyrometer plays only the role of a zero instrument, and the transmission is 
found independently of the monochromator. It is to be noticed, that in this method the determination of the wave-length interval in which the radiation is measured must be carried out very carefully at each of the spectral regions.

After this, if an absolute standardization is required, the total radiation of the lamp is measured by a bolometer specially adapted to this work (i). Two strips of manganin are juxtaposed, the one is irradiated, the other is heated by an electric current till equality of temperature is obtained; by various refinements (8), especially by a very exact method of determining the area of the strips, it is possible to attain an accuracy of $0.1 \%$. In this determination, a colour filter has to be interposed, for the absorption of the bolometer strip has only been determined in the visual part of the spectrum. But from the known transmission of the filter and the relative energy distribution of the source, it is easy to calculate what fraction of the total radiation has been received by the bolometer and to account for that.

Secondary standardization. Here we make use of the emission coefficients of tungsten determined by Worthing, or of the reflection coefficients ( $=I-$ abs. coeff.) determined by Hamaker. We measure the brightness temperature of our ribbon

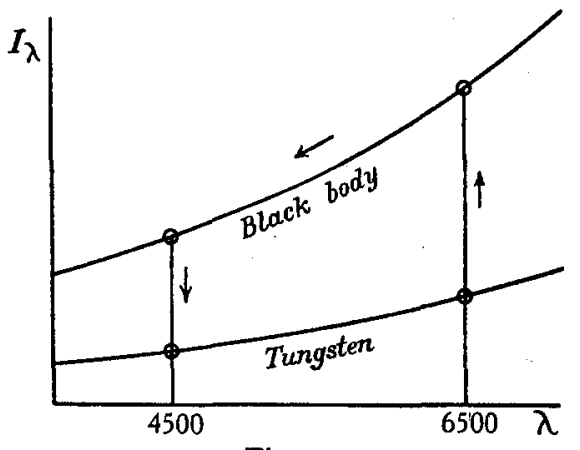

Fig. 3.

lamp, say in the red; by the emission coefficient we deduce the brightness which the black body would have there, and so the true temperature of the ribbon. At any other wave-length we calculate the emission from the black body emission, multiplied by the emission coefficient for that particular wave-length (Fig. 3). The transmission of the window must be determined by a ray of light passing at the side of the ribbon, and there must be a correction for it.

The way in which Hamaker measured the reflection coefficient of tungsten is as follows (7). He placed the ribbon inside a cylinder, painted with zinc white and containing two incandescent lamps, so that it was homogeneously illuminated; he then compared the brightness of the ribbon with the brightness of the walls. This method is independent of any irregularities of the surface of the ribbon and gives very constant results; it is an application of the principle of reciprocity of Helmholtz.

This secondary standardization depends on the pyrometer scale, which once for all has been tested by comparison with a black body at the melting point of gold (3) It will be seen that the method gives not only a relative, but at the same time an absolute standardization.

Spiral lamps are calibrated by simpler methods, e.g. by measurement of the intensity ratio for two colours and comparison with a ribbon lamp. When careful selection is exercised between the lamps, a colour temperature exists between $\lambda 4000$ 
and $\lambda 7000$. Distinction should be made between the $T_{c}$ of the whole filament, and the $T_{\mathrm{c}}$ of the central turns.

In all measurings of the radiation of lamps and of the transmission of reducers, it is essential that the photometric receiver should be exactly linear. This is tested in the easiest way by irradiating with two sources of light, and screening off consecutively the one and the other; the deflection for $I_{1}+I_{2}$ must be equal to the sum of the deflections for $I_{1}$ and for $I_{2}$.

It is not easy to say just how long the calibrations of a lamp remain unaltered. For temperatures under $275^{\circ}$, about 300 hours is probably the limit. For temperatures of $2900^{\circ}$, no change was found after Ioo hours. Absolute calibrations of the intensity in ergs are valid during at least 40 hours.

\section{BIBLIOGRAPHY}

(I) H. C. vaN ALPHEN. Stralingsmeting aan wolfraamlampen. Diss., Utrecht, r927.

(2) L. S. Ornstein, D. Vermeulen and E. F. M. van DER Held. Calibration of standard lamps for relative and absolute measurements. J. Opt. Soc. Amer. 20, 573, 1930.

(3) D. Vermeuren, L. S. ORNSTein and J. WoudA. Anschluss der Utrechter Strahlungs- und Temperaturmessungen an Messungen am schwarzen Körper mittels des Goldpunktes. Proc. Acad. Sci. Amst. 34, 985, 1930.

(4) L. S. ORNSTEIN, W. H. J. MoLI and H. C. BURGER. Objektive Spektralphotometrie. Vieweg, 1932.

(5) L. S. ORnstern. Unité de lumière ou méthode standardisée de mesure? Rev. d'Opt. 12, $385,1933$.

(6) L. S. ORNSTein, J. G. Eymers and D. Vermeulen. Une méthode simple et exacte pour la standardisation d'étalons secondaires de temperature arbitraire. Rev. d'Opt. 12, 390, I933.

(7) H. C. Hamaker. Reflectivity and emissivity of tungsten. Diss., Utrecht, I934.

(8) D. Vermeulen. An accurate method for the relative measuring of spectral intensities. Diss., Utrecht, 1935 .

(9) J. Wouda. Nauwkeurige absolute intensiteitsmeting. Diss., Utrecht, I935.

(IO) H. KIENLE. Uber Eigentümlichkeiten von Neutralfiltern aus Platin. Zs.f. Ap.4, 282, I932.

\section{Dispositifs Nouveaux Utilisables en Spectrophotométrie Stellaire}

Par Daniel Chalonge

Ces dispositifs sont utilisés par Barbier, Chalonge et Vassy dans les études qu'ils poursuivent actuellement sur la distribution de l'énergie dans les spectres continus des étoiles des premiers types spectraux. Ils ont été décrits dans diverses publications que résume le présent article. Il ne s'agira ici que de spectrophotométrie photographique.

\section{(I) Elargissement des spectres stellaires par astigmatisme}

Les valeurs (relatives en général) des intensités des radiations que l'on étudie se déduisent de la mesure des noircissements des points correspondants des spectres photographiés. Or, une étoile donnant normalement un spectre, sinon filiforme, du moins de hauteur très faible, les plages dont il faut mesurer le noircissement ont une surface extrêmement réduite: il en résulte une grande difficulté de mesure et une faible précision. Aussi est on conduit à élargir les spectres. Malheureusement les procédés d'élargissement généralement employés sont des procédés mécaniques (traînage, déplacement de la plaque dans son plan) et ils conduisent à des difficultés d'ordre photographique: les divers points d'une même raie sont impressionnés 
successivement et le temps de pose, donnée fondamentale en photométrie photographique, est mal déterminé.

Cette difficulté peut être tournée grâce à l'emploi d'un procédé purement optique. Suivant la méthode proposée par Couder(1), Chalonge et Vassy ont construit un spectrographe à prisme objectif donnant des spectres élargis par astigmatisme (2). Le prisme, de $60^{\circ}$, est suivi d'un objectif de chambre, constitué par une lentille satisfaisant à la condition des sinus pour la radiation moyenne du domaine spectral étudié. On incline de quelques degrés cette lentille autour de son diamètre parallèle à l'arête du prisme. De la sorte, les diverses images monochromatiques ponctuelles de l'étoile sont remplacées chacune par un système de deux focales et les diverses focales tangentielles se placent côte à côte et constituent un spectre dont la hauteur dépend de l'inclinaison de la lentille. Le noircissement est constant dans toute la hauteur des raies si le faisceau incident a une section rectangulaire, c'est à dire si le faisceau sortant du prisme n'est pas diaphragmé par la lentille. Deux spectrographes à optique de quartz ont été réalisés sur ce principe.

A l'usage, un autre avantage de l'élargissement par astigmatisme est apparu. L'astigmatisme, et par suite la hauteur de chaque focale tangentielle, croît lorsque l'angle que fait le faisceau correspondant avec l'axe principal de la lentille croît: il varie donc d'un bout à l'autre du spectre et le spectre est plus étalé en hauteur à l'une de ses extrémités qu'à l'autre. En inclinant la lentille dans le sens convenable, on peut s'arranger, dans les cas d'une optique de quartz, pour que le visible soit plus étalé en hauteur que l'ultraviolet. Par ce moyen on peut obtenir des noircissements notablement plus forts dans l'ultraviolet que ceux que donnerait un spectrographe ordinaire, pour un même noircissement dans le domaine visible. Il serait, inversement, possible en inclinant la lentille dans l'autre sens d'accroître le noircissement dans l'infra rouge.

\section{(2) Le tube à hydrogène, source terrestre de comparaison}

Pour étudier la répartition de l'énergie dans les spectres stellaires il faut les comparer, directement ou indirectement, au spectre d'une source terrestre dont la courbe d'énergie soit bien connue. Mais il est difficile de trouver une source terrestre aisément comparable aux spectres des étoiles des premiers types spectraux, notamment dans l'ultraviolet: la température de couleur des sources de comparaison employées jusqu'ici (sources incandescentes, flamme d'acétylène) est en effet beaucoup plus faible que celle de ces étoiles. Cependant, de bons résultats ont été obtenus récemment par Barbier, Chalonge et Vassy grâce à l'emploi, comme spectre de comparaison, du spectre continu de la molécule d'hydrogène. Ce spectre est produit par un tube à décharges excité par un courant électrique.* Il a les avantages d'être facile à produire, stable, peu sensible aux conditions de la décharge et d'être très comparable aux spectres continus des étoiles des premiers types.

Le tube à décharges comprend une partie rectiligne cylindrique ayant $I 2 \mathrm{~cm}$. de longueur environ et un diamètre de 3 à $6 \mathrm{~mm}$. le "capillaire", prolongé par deux parties de plus gros diamètre contenant des électrodes d'aluminium cylindriques, coaxiales au tube. Il.est fermé par une fenêtre de quartz permettant l'observation en bout. Le tube est rempli d'hydrogène pur et sec sous une pression de l'ordre de $3 \mathrm{~mm}$. de mercure. On l'excite par un courant de quelques milliampères (de 5 à 300 millis) sous rooo volts environ, fourni par le secondaire d'un transformateur alimenté par le secteur.

* Tube à hydrogène de Chalonge et Lambrey, construit par la S.C.A.D. 
Le spectre émis comprend les 3 ou 4 premières raies de Balmer, faibles, les raies du spectre secondaire, assez faibles également et pratiquement inexistantes au-dessous de $3800 \mathrm{~A}$., et le très remarquable spectre continu moléculaire qui s'étend du visible à la région de Schuman. La courbe représentant la variation de l'énergie en fonction de la longueur d'onde a été déterminée par comparaison au spectre d'un corps noir: l'énergie croît régulièrement lorsqu'on se déplace vers les courtes longueurs d'onde (elle croît sûrement jusque vers $2400 \mathrm{~A}$., peut-être plus loin). Dans le domaine ultraviolet, cette courbe se rapproche beaucoup de celles des étoiles B, sans pouvoir toutefois être assimilée à celle d'un corps noir.

Lorsque l'intensité du courant change, cette courbe se déforme mais très légèrement: les intensités des diverses radiations croissent en effet à peu près proportionnellement, lorsque le courant augmente, de sorte que le rapport des intensités de deux radiations quelconques est à peu près indépendant du courant. La courbe d'énergie est également très peu sensible aux variations de la pression d'hydrogène: ces variations de pression déterminent surtout un changement dans le rapport de l'intensité moyenne des raies à celle du fond continu.

Deux tubes analogues fonctionnant sous des régimes voisins émettent très sensiblement le même spectre continu.

Le principal inconvénient du spectre continu moléculaire de l'hydrogène est qu'il est faible dans le domaine visible. Au-dessus de 4500 A., il s'y superpose d'ailleurs les raies nombreuses du spectre secondaire si bien que l'usage du tube doit être à peu près limité aux radiations de longueurs d'onde plus courtes que $4500 \mathrm{~A}$. On pouvait craindre que des difficultés d'ordre photographique ne surgissent si l'on voulait comparer le spectre d'une étoile-constant dans le temps-au rayonnement intermittent émis par le tube à hydrogène excité en courant alternatif. Chalonge et $\mathrm{Ny}$ Tsi-Zé(6) ont montré que le noircissement produit par le spectre du tube ainsi excité est identique à celui que produirait le même tube excité par un certain courant continu sous haute tension: les difficultés soupçonnées n'existent donc pas.

Les quelques indications qui précèdent (et qui résument une étude plus complète faite par l'auteur (7)) montrent tout l'intérêt que présente l'emploi du tube à hydrogène comme source de référence pour les études spectrophotométriques entre le bleu et l'ultraviolet.

\section{(3) Emploi d'une étoile artificielle, de magnitude variable, pour l'obtention des courbes de noircissement}

La détermination correcte de ces courbes constitue l'un des problèmes les plus importants de la photométrie photographique. Il est nécessaire, si l'on veut faire des mesures précises, de déterminer avec soin les courbes correspondant à de nombreuses radiations.

Dans diverses recherches de spectrophotométrie stellaire $(3,4,5)$ ou géophysique $(2)$, Barbier, Chalonge et Vassy ont employé la méthode suivante. Une étoile artificielle est constituée par une source de lumière (généralement un tube à hydrogène) placée au foyer d'une lentille condensatrice qui dirige le faisceau sortant vers le spectrographe. L'ensemble, source-lentille, est placé à une distance suffisante (quelques centaines de mètres) pour que le spectrographe (a prisme objectif), réglé pour l'infini, puisse en donner un spectre net. La lentille condensatrice a un diamètre assez petit ( 3 ou $4 \mathrm{~cm}$.) et une distance focale assez grande $(50 \mathrm{~cm}$.) pour que son éclairement soit uniforme. Pour un observateur placé à côté du spectrographe, la lentille joue le rôle d'une source de lumière qui aurait une brillance 
uniforme égale à la brillance moyenne de la source réelle. Il suffit donc de recouvrir cette lentille de diaphragmes de surface connue pour faire varier dans des rapports déterminés la magnitude de l'étoile artificielle, l'intensité de toutes ses radiations étant modifiée dans le même rapport. En prenant successivement une série de spectres correspondant à des valeurs diverses du diaphragme on possede tous les éléments nécessaires pour le tracé des courbes de noircissement.

\section{BIBLIOGRAPHIE}

(1) C.R. Acad. Sci., Paris, 197, x199, 1933.

(2) Rev. d'Opt. 13, I13, 1934; et J. Phys. Radium, 5, 309, 1934.

(3) Rev. d'Opt. 13, I99, 1934.

(4) J. Phys. Radium, 6, 137, 1935.

(5) C.R. Acad. Sci., Paris, 20r, 128, 1935.

(6) Rev. d'Opt. 9, I45, I930.

(7) Ann. Phys., Lpz., I, I23, 1934.

\section{The Greenwich Methods of Spectrophotometry}

\section{By W. M. H. Greaves}

From time to time various details of the spectrophotometric work at Greenwich have been published. I do not propose to recapitulate these to-day, but rather I propose to spend the available time in discussing a few points which have so far not been elaborated in print.

As Dr Minnaert has said, the two major problems are those of standardization and calibration. With regard to the second of these I should like to mention some control observations which have been taken in connection with our current programme. The Greenwich plates are calibrated, or scaled as we prefer to express it, with a multiple slit spectrograph. This scale spectrograph has been described in a Greenwich publication issued three years ago.* In the same publication the method of measuring the slit widths by the use of exposures with full and half apertures was also described. This method of scaling is completely fundamental in itself, but it is not at all obvious whether it is justifiable to reduce exposures made with the telescope by means of the scale exposures. The conditions are very different. The telescope exposures are essentially intermittent, the broadening of each spectrum being secured by trailing the image to and fro on the plate, whereas the exposures made with the scale spectrograph are continuous. It might thus be expected that the characteristic curves obtained from the scale exposures need correction before they are applied to the reduction of the stellar spectra.

In order to determine these corrections the method of full and half apertures is again utilised, a series of control plates being taken with the telescope as follows. On a given star an exposure is made with the full 36 -inches aperture, a second exposure is then made, with the same exposure time; half of the aperture being obscured by a shutter. Still keeping to the same exposure time a third exposure is made with the other half of the aperture obscured. In the case of a slit spectrograph the half aperture shutters may be conveniently mounted immediately behind the collimator. $\dagger$

For a given wave-length denote the light flux for the full aperture by $I$ and denote the light fluxes with the half aperture exposures by $I_{2}$ and $I_{3}$. The spectra are

* Observations of Colour Tomperatures of Stars, 1932, p. I3.

$\dagger$ For the Greenwich slitless spectrograph they are immediately before the prism. 
measured and reduced by means of the characteristic curves obtained from the measures of the calibration exposures with the scale spectrograph, and the following quantities are thus obtained:

$$
\begin{aligned}
2 a & =I_{2} / I, \\
2 b & =I_{3} / I, \\
c & =-5 / 2 \log (a+b) .
\end{aligned}
$$

Now no matter what the inequalities of the optical train may be, we must have $I_{2}+I_{3}=I$, and so we must have $c=0.75$ magnitudes. Suppose that as measured with the aid of the calibration curves $c=0.78$. It would then follow that, whenever a magnitude difference of 0.75 was being measured by means of telescope exposures the difference, as measured and reduced by the use of the calibration curves obtained from the measures of the scale spectrograph exposures, needs correction by the factor 75/78. And, for work in the neighbourhood of the point of inflection of the $H$ and $D$ curve (density against $\log$ intensity), this factor is applicable to all magnitude differences obtained from the reduction of the plates.

We have also found it convenient to maintain a standard exposure time for the scale spectrograph exposures and to take control plates with full and half apertures using various exposure times with the telescope. In this way the variation of contrast factor with exposure time may be taken into account.*

The control plates are interspersed among the ordinary plates of the current programme. They are calibrated with the other plates and in fact are treated in the same way. The correcting factors obtained from them will thus include any corrections that may exist for errors depending on the history of the plate, such as growth of latent image.

Turning to the question of standardization, our colour temperature work, in the course of which we have measured the energy distribution through the visible spectrum for certain standard stars of types B and A, has been described in the Greenwich publication referred to above and in Monthly Notices, 94, 488, I934. There seems for these stars to be a slight departure from Planck's black body distribution, the intensity at $\lambda 5300$ being rather less than that given by a Planck curve fitted to the measures at $\lambda 4600$ and $\lambda 6000$. But this result is to be regarded as tentative, and in point of fact it is to be observed that our colour temperatures derived from measures over the range $\lambda 4400$ to $\lambda 6500$ are in strikingly good agreement with the mean results obtained by Barbier, Chalonge and Vassy, who gave colour temperatures derived from measures over the range $\lambda 3700$ to $\lambda 4500$. The departures from the Planck curve for the stars of early type are certainly very small

* Note added 1935, December 16. A series of $4^{\circ}$ control plates has now been taken and measured. These give the following result:

$$
f=\alpha+\beta \log t
$$

where $f$ is the correcting factor by which magnitude differences derived from the scale spectrograph calibrations are to be divided, and $t$ is the telescope time in seconds, the values of $t$ ranging from 20 to 540 seconds. The numerical values of $\alpha$ and $\beta$ given by a least square solution are

$$
\begin{aligned}
& \alpha=0.890 \pm 0.011, \\
& \beta=0.075 \pm 0.011 .
\end{aligned}
$$

The plates used were Ilford "Hydrogen-Alpha". They were developed in dilute pyro-soda for ro minutes at $60^{\circ}$ Fahrenheit. 
and probably do not amount to more than two or three per cent. between the Balmer and Paschen limits.

The laboratory standards in our absolute work were tungsten filament lamps whose colour temperatures had been measured by the National Physical Laboratory, using colour-matching methods. I wish to emphasise my opinion that absolute work should be confined to the measurement of the energy distribution of a selected number of standard stars which have been extensively inter-compared among themselves by relative measurements at equal altitudes. Measurements for other stars can then be obtained by equal altitude comparisons with one or more of the standards.

\section{GÖTTINGEN SPECTROPHOTOMETRY}

By H. KIENLE

Die Göttinger spektralphotometrischen Untersuchungen haben zum Ziel die Bestimmung der wahren Energieverteilung im kontinuierlichen Spektrum ausgewählter Sterne aller Spektralklassen. Aus diesen Energieverteilungen lassen sich mit Hilfe der inzwischen entwickelten Theorie des Absorptionsprozesses in Sternatmosphären (1) effektive Sterntemperaturen ableiten. Im Dienst dieser Aufgabe stehen zur Zeit 3 Instrumente:

(a) Objektivprismenkamera (OPK) mit UV-Triplet, $\mathrm{O}=15 \mathrm{~cm} ., f=150 \mathrm{~cm}$., UV-Prisma $50^{\circ}$, Dispersion $35 \mathrm{~A} . / \mathrm{mm}$. bei $\lambda 4000$.

(b) Spiegelprismenkamera (SPK), $\mathrm{O}=\mathrm{I} 6 \mathrm{~cm} ., f=145 \mathrm{~cm}$., UV-Prisma $8^{\circ}+\mathrm{I} 2^{\circ}$, Dispersion $\mathrm{I}_{50} \mathrm{~A} . / \mathrm{mm}$. bei $\lambda_{5000}$.

(c) Objektivprismen-Quarzspektrograph (QPK), $\mathrm{O}=\mathrm{I} 5 \mathrm{~cm} ., f=90 \mathrm{~cm}$, zwei $30^{\circ}$-Prismen in Young-Anordnung, Dispersion $30 \mathrm{~A} . / \mathrm{mm}$. bei $\lambda 3500$.

Das Hauptprogramm, das zunächst mit den beiden ersten Instrumenten durchgeführt wird, umfaßt 37 Sterne (vgl. die Liste im Anhang) und wird in zwei Schritten erledigt:

(a) Vergleiche der Sterne untereinander in einem geschlossenen Netz von rund Ioo Verbindungen (Relativer Anschluß).

(b) Vergleiche von Io B- und A-Sternen mit dem Schwarzen Körper unter Zwischenschaltung einer Wolfram-Bandlampe als sekundäre Normale (Absoluter Anschluß).

Der Nullpunkt des Systems wird außerdem noch festgelegt durch Vergleiche von $\gamma, \epsilon, \eta$ Ursae Majoris mit 4 G-Zwergen, für deren Energieverteilung die der Sonne angesetzt werden kann, unter Berücksichtigung der Verschmierung der Absorptionslinien infolge ungenügender Auflösung. Die photometrische Skala wird durchwegs mit Hilfe von Paralleldrahtgittern gewonnen, deren photometrische Konstanten nach verschiedenen Methoden (geometrische Ausmessung, energetische Eichung im Laboratorium, photographische Eichung mit Hilfe von Sternen) bestimmt werden. Die Spektra werden mit einem Zeiß-Photometer registriert.

Die Beobachtungen für den relativen Anschluß sind abgeschlossen und die Reduktionen gefördert bis zur Ausgleichung des Netzes. Mit wenigen, durch die Witterung bedingten, Ausnahmen, sind alle Verbindungen mindestens 5-mal beobachtet. OPK hat mit großer Dispersion den Bereich 3600-5000 erfaßt, SPK mit kleiner Dispersion den Bereich 3600-6600. Die endgültige Festlegung der photometrischen Skala erfordert noch einige Untersuchungen über die Fehler der verwendeten Gitter. 
Die Beobachtungen für den absoluten Anschluß, die eine Absolutbestimmung der Extinktion einschließen, sind im Gang. Als Instrument dient OPK mit panchromatischen Filmen; Bereich 3600-6600. Die Vergleiche mit dem künstlichen Stern erfolgen genau wie bei den relativen Anschlüssen photographisch, unter Benützung des Gitters. Alle anderen Reduktionselemente (Lampenstrahlung, Filterdurchlässigkeiten, Verluste in der Optik) werden im Laboratorium mit Hilfe von Photozellen absolut gemessen.

Die ebenfalls mit OPK im Bereich $3600-6600$ gesondert durchgeführten Vergleiche der 3 Ursa-Sterne mit den 4 G-Zwergen liegen fertig bearbeitet vor, bis auf eine letzte Diskussion des Einflusses der Gitterschwankungen auf die Skala.

Außer dem fundamentalen Programm laufen noch folgende Arbeiten:

(x) Ausgewählte B-Sterne mit verschiedenem Farbenexcess werden mit Fundamentalsternen verglichen; OPK 3600-6600, QPK 3000-5000.

(2) Relative Anschlüsse eines Teils der Fundamentalsterne und einiger Zusatzsterne (insgesamt 22 Sterne) im Infrarot; SPK 6600-8400.

(3) Untersuchung von Einzelobjekten mit QPK (B- und A-Sterne, Planetarische Nebel, Nova). Vorbereitung des absoluten Anschlusses im UV, der aber erst durchgeführt werden kann, wenn es gelingt, das Instrument an einem geeigneten Beobachtungsort aufzustellen.

\section{LITERATUR}

(I) L. Biermann. Veröff. Univ. Sternw. Göttingen, Nr. 34 und 37; Vjschr. astr. Ges., Lpz., 68, 316, I933.

A. UNSÖLD. Z. f. Ap. 8, 32 und $225,1934$.

(2) Uber die spektralphotometrischen Untersuchungen. Veröff. Univ. Sternw. Göttingen, Nr. II, $12,25,28,29$.

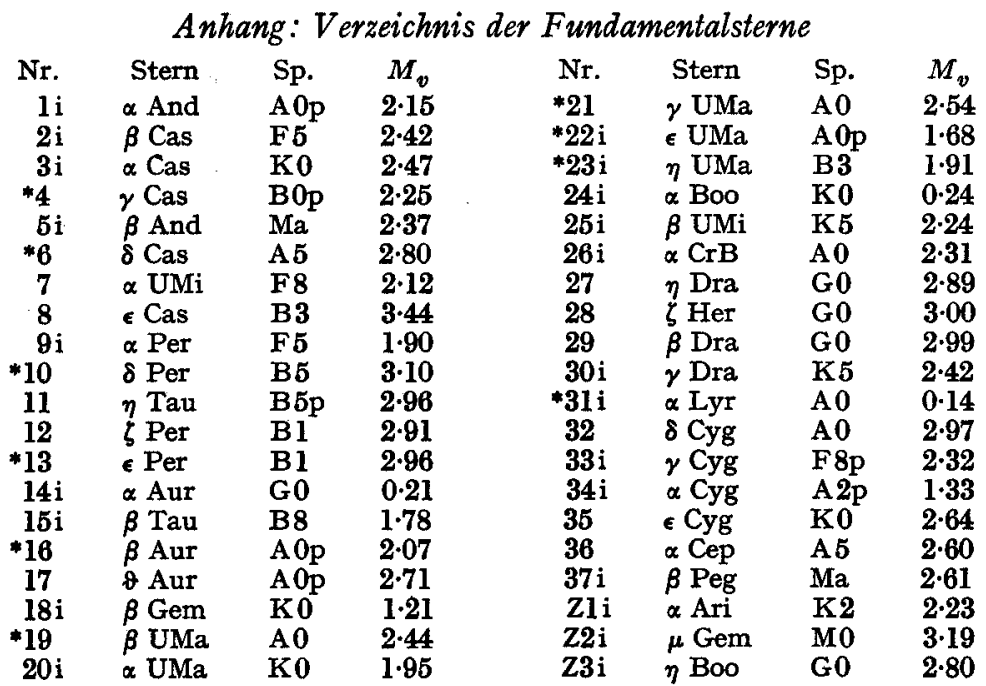

Bemerkungen. Die Sterne des absoluten Anschlusses sind mit * bezeichnet, die des InfrarotProgramms mit i. Die Sterne 7, 8, 11 sind nur im gewöhnlichen photographischen Bereich beobachtet. 